\title{
Disposisi Matematis Langsung dan Tidak Langsung: Karakteristisasi Disposisi Matematis Berdasarkan Gestur
}

\author{
Okta Pita Dian Sari ${ }^{1}$, Surya Sari Faradiba ${ }^{2}$ \\ 1,2 Magister Pendidikan Matematika, Program Pascasarjana, Universitas Islam Malang, \\ Jalan Mayjen Haryono No.193, Dinoyo, Kec. Lowokwaru, Kota Malang, Jawa Timur 65144 \\ suryasarifaradiba@unisma.ac.id
}

\begin{abstract}
This study aims to explore the characterization of students' mathematical dispositions based on students' gestures in solving linear programming problems. This research method uses qualitative research with a grounded theory design. The research was carried out in the odd semester of the 2020/2021 academic year in class XI MAN Batu City. The instruments used include questions about linear programming material, observation sheets based on three categories of gestures, and interview guidelines with grids based on characterization of mathematical dispositions. The subject consists of two students. The process of selecting subjects by convenience sampling. Two subjects were selected from 22 students who took the initial ability test. Two subjects whose initial abilities were met will then be explored regarding the characterization of their mathematical dispositions through problem-solving tests, interviews, and observations. Data analysis shows that the dominant type of gesture is representational gesture. S1 shows three representational gestures, while S2 shows two representational gestures. Based on the gestures that appear, clues are obtained to reveal the characteristics of mathematical dispositions, namely direct and indirect. In this study, S1 indicates a direct disposition, while S2 indicates a direct and indirect disposition. Direct disposition describes the problemsolving process that occurs instantly when students encounter obstacles. Meanwhile, indirect disposition shows the problem-solving process that only occurs a few moments after students encounter obstacles.
\end{abstract}

Keywords: Direct Mathematical Disposition, Indirect Mathematical Disposition, Gesture

\begin{abstract}
Abstrak
Penelitian ini bertujuan untuk mengeksplorasi karakterisasi disposisi matematis siswa berdasarkan gestur siswa dalam menyelesaikan masalah program linear. Metode penelitian ini menggunakan penelitian kualitatif dengan desain grounded theory. Penelitian dilaksanakan pada semester ganjil tahun ajaran 2020/2021 di kelas XI MAN Kota Batu. Instrumen yang digunakan meliputi soal tentang materi program linear, lembar observasi yang disusun berdasarkan tiga kategori gestur, dan pedoman wawancara dengan kisi-kisi yang dibuat berdasarkan karakterisasi disposisi matematis. Subjek terdiri dari dua siswa. Proses pemilihan subjek secara convenience sampling. Dua subjek dipilih dari 22 siswa yang melaksanakan tes kemampuan awal. Dua subjek yang kemampuan awalnya terpenuhi kemudian dieksplorasi mengenai karakterisasi disposisi matematisnya melalui tes penyelesaian masalah, wawancara dan observasi. Analisis data menunjukkan bahwa jenis gestur yang mendominasi adalah gestur representasi. S1 menunjukkan tiga kali gestur representasi, sedangkan S2 menunjukkan dua kali gestur representasi. Berdasarkan gestur yang muncul diperoleh petunjuk untuk mengungkapkan karakteristik disposisi matematis, yakni langsung dan tidak langsung. Dalam penelitian ini, S1 menunjukkan disposisi langsung, sedangkan S2 menunjukkan disposisi langsung dan tidak langsung. Disposisi langsung menggambarkan proses penyelesaian masalah yang terjadi seketika saat siswa menemui hambatan. Sedangkan, disposisi tidak langsung menunjukkan proses penyelesaian masalah yang baru terjadi beberapa saat setelah siswa menemui hambatan.
\end{abstract}

Kata kunci: Disposisi Matematis Langsung, Disposisi Matematis Tidak Langsung, Gestur

Copyright (c) 2022 Okta Pita Dian Sari, Surya Sari Faradiba

$\triangle$ Corresponding author: Surya Sari Faradiba

Email Address: suryasarifaradiba@unisma.ac.id (Jalan Mayjen Haryono No.193 Kota Malang, Jawa Timur)

Received 22 December 2021, Accepted 05 February 2022, Published 02 March 2022

\section{PENDAHULUAN}

Setiap siswa akan memiliki respon yang berbeda dalam menyelesaikan masalah. Hal tersebut dikarenakan oleh beberapa faktor seperti pendidik, keluarga, metode yang digunakan pendidik, motivasi belajar, dan intelegensi (Kurnia, dkk, 2014). Selain itu, ada faktor internal yang berasal dari dalam diri siswa dan faktor eksternal yang berasal dari luar siswa (Wahab, 2015). Disposisi matematis 
adalah salah satu faktor internal yang mempengaruhi siswa dalam menyelesaikan masalah. Disposisi merupakan bagian dari afektif seseorang yang penting untuk dapat mencari solusi dalam menghadapi masalah (Hendriana \& Kadarisma, 2019). Disposisi matematis ditunjukkan melalui sikap positif seperti kepercayaan diri, keingintahuan, ketekunan dalam belajar, gigih dalam menghadapi suatu masalah, cepat tanggap, simpati dan aktif dalam pembelajaran (Wardani, 2012). Namun, disposisi matematis tidak hanya sebatas sikap tetapi juga kecenderungan untuk berpikir maupun bertindak dengan cara yang positif (NCTM, 1989). Salah satu kecenderungan berpikir maupun bertindak siswa dapat dilihat pada saat menyelesaikan suatu masalah. Sari, dkk (2021); Miatun, dkk (2021) mengemukakan bahwa dalam menyelesaikan masalah terdapat pengaruh disposisi matematis. Oleh karena itu, disposisi matematis berpengaruh dalam menyelesaikan suatu masalah.

Siswa dalam menyelesaikan masalah memiliki ekspresif yang bervariasi. Ada yang cenderung bersikap diam dan fokus menulis serta ada yang menunjukkan sikap banyak gerak. Sejalan dengan Harun dkk (2019) pada saat menyelesaikan masalah siswa akan menunjukkan gerak atau gestur yang bervariasi sehingga sikap yang dihasilkan juga bervariasi. Menurut Achadiyah (2017); Damayanti (2018) gestur merupakan tindakan anggota tubuh secara tidak sadar bersamaan dengan keluarnya ucapan atau wujud tulisan. Gestur dapat memunculkan karakter-karakter baru saat menyelesaikan suatu permasalahan, selain itu gestur dapat menjadi alat penelitian yang efektif (Williams, dkk, 2017). Dalam artian, gestur dalam penelitian ini merupakan bentuk dari karakterisasi disposisi matematis dalam menyelesaikan suatu masalah program linear.

McNeill (dalam Achadiyah, 2017) mengategorikan empat gestur yang dimiliki siswa, yaitu gerakan yang ditunjukkan bersamaan dengan ucapan (gesture iconic), gerakan dengan menunjuk ke objek yang ingin dituju (gesture deictic), gerakan yang memberikan suatu irama (gesture beat), dan gerakan yang menggambarkan suatu emosi (gesture metaphoric). McNeill (dalam Alibali \& Nathan, 2012) mengklasifikasikan menjadi tiga kategori, yaitu (1) gestur menunjuk (pointing gesture), (2) gestur representasi (representation gesture), dan (3) gestur menulis (writing gesture). Gestur menunjuk membahas mengenai gesture deictic pada pengkategorian McNeill. Gestur representasi membahas mengenai gesture iconic dan gesture metaphoric. Sedangkan gestur menulis tidak memberikan gambaran mengenai gerakan secara luas, semua yang ada dalam pikiran dituangkan dalam bentuk tulisan.

Gerakan visual yang memberikan hubungan antara menggambarkan suatu objek yang abstrak ataupun kondisi emosional yang terjadi disebut gestur representasi (Sulistyorini, dkk, 2019). Gestur menunjuk adalah gerakan yang dikaitkan antara proses bicara dan sikap yang melibatkan anggota tubuh seperti ibu jari, jari telunjuk ataupun alat tulis seperti bolpoin sebagai perantara (Yuli \& Siswono, 2019). Gestur menulis adalah gerakan tangan yang disama artikan dengan penjelasan yang dituliskan (Sulistyorini, dkk, 2019). Lembar penyelesaian siswa sebagai tanda yang ditinggalkan pada gestur tulis. Fungsi dari gestur menulis tidak lain untuk mengetahui apa yang sudah diketahui dalam pikirannya sebagai bentuk akhir yang dituangkan dalam tulisan, dapat mewujudkan dalam bentuk 
tulisan dari sesuatu yang sedang dihitung, dan mengarahkan proses berpikir dari mengetahui langkah sebelumnya saat menghitung ke langkah berikutnya dalam menyelesaikan masalah (Achadiyah, 2017).

Salah satu masalah yang sering dijumpai dalam matematika ada pada materi program linear yang diajarkan pada siswa kelas XI. Banyak siswa merasa kesulitan dalam menyelesaikan masalah program linear (Andriyani \& Ratu, 2018). Sejauh ini, belum ada penelitian yang membahas mengenai karakterisasi disposisi matematis dengan pengamatan gestur dalam menyelesaikan masalah pada materi program linear. Adapun penelitian Akbar, dkk (2018); Sari, dkk (2021); Miatun, dkk (2021) membahas mengenai disposisi matematis yang diukur berdasarkan angket dan ketiga penelitian tersebut tidak menggunakan materi program linear. Oleh karena itu, penelitian ini bertujuan untuk mengeksplorasi karakterisasi disposisi matematis berdasarkan gestur siswa dalam menyelesaikan masalah program linear.

\section{METODE}

Metode penelitian ini menggunakan penelitian kualitatif dengan desain grounded theory terhadap siswa yang kemampuan awalnya terpenuhi pada materi sistem persamaan dan pertidaksamaan dua variabel. Penelitian ini dilaksanakan pada semester ganjil tahun ajaran 2020/2021 di kelas XI MAN Kota Batu. Instrumen yang digunakan dalam penelitian ini meliputi soal tentang materi program linear, lembar observasi yang disusun berdasarkan tiga kategori gestur, dan pedoman wawancara dengan kisi-kisi yang dibuat berdasarkan karakterisasi disposisi matematis. Subjek penelitian terdiri dari dua siswa yang dipilih secara convenience sampling. Dua subjek dipilih dari 22 siswa yang melaksanakan tes kemampuan awal. Dua subjek yang kemampuan awalnya terpenuhi kemudian akan dieksplorasi mengenai karakterisasi disposisi matematisnya melalui tes penyelesaian masalah, wawancara dan observasi. Dalam menguji kredibilitas, penelitian ini menggunakan triangulasi teknik yang membandingkan hasil tes, observasi dan wawancara sehingga diperoleh data yang valid.

Kastolan (dalam Sulistiyaningsih, 2017), mengkategorikan kesalahan menjadi tiga yaitu, kesalahan konseptual, kesalahan prosedural, dan kesalahan teknik. Sehingga dalam menyelesaikan masalah diperlukan tiga penguasaan. Berdasarkan teori kastolan, tes kemampuan awal pada penelitian ini terdiri dari dua puluh soal, empat soal penguasaan prosedural, lima soal penguasaan konseptual, tujuh berupa penguasaan teknik, dan empat soal penguasaan gabungan (prosedural, konseptual, dan teknik). Selanjutnya, tes penyelesaian masalah terdiri dari satu soal uraian mengenai program linear yang dapat dilihat pada gambar 1 . Tes ini diberikan untuk dua siswa yang telah dipilih untuk memunculkan variasi gestur saat proses menyelesaikan masalah. 
Dita ingin menjual dua jenis kue yaitu kue bolu dan brownies. Di lemari dapur terdapat 8 $\mathrm{kg}$ tepung dan $2 \mathrm{~kg}$ gula pasir. Kue bolu membutuhkan 10 gram gula pasir dan 20 gram tepung sedangkan kue brownies membutuhkan 5 gram gula pasir dan 50 gram tepung. Jika kue bolu dijual dengan harga Rp 300,00/buah dan kue brownies dijual dengan harga Rp 500,00/buah, tentukanlah pendapatan maksimum yang dapat diperoleh pembuat kue tersebut.

\section{Gambar 1. Soal Uraian Program Linear}

Saat pemberian tes penyelesaian masalah, peneliti secara bersamaan melakukan observasi. Bukti pengamatan yang digunakan dalam penelitian ini berupa video selama siswa menyelesaikan masalah dengan estimasi waktu 40 menit. Observasi digunakan untuk mengamati siswa dalam menyelesaikan masalah program linear sehingga peneliti berhasil mengeksplorasi gestur yang ditunjukkan oleh siswa. Adapun gestur yang digunakan dalam penelitian ini ditunjukkan pada Tabel 1.

Tabel 1. Jenis Gestur Tangan

\begin{tabular}{|l|l|}
\hline Gestur Tangan & \multicolumn{1}{c|}{ Keterangan } \\
\hline Menulis & $\begin{array}{l}\text { Siswa fokus menggerakan pena di atas kertas untuk menuangkan } \\
\text { pemikirannya }\end{array}$ \\
\hline Menunjuk & Siswa memberikan gerakan dengan menunjuk ke objek yang ingin dituju \\
\hline Representasi & $\begin{array}{l}\text { Siswa memberikan gerakan bebas untuk menggambarkan kondisi } \\
\text { emosional ataupun menuangkan apa yang ada dalam pikirannya }\end{array}$ \\
\hline
\end{tabular}

Namun, untuk mendapatkan data lebih lengkap mengenai gestur diperlukan wawancara. Jenis wawancara yang digunakan dalam penelitian ini adalah semi terstruktur. Pertanyaan muncul saat proses penyelesaian masalah berlangsung (wawancara seketika) dan setelah penyelesaian masalah selesai. Wawancara digunakan untuk mengkonfirmasi jika terjadi suatu hambatan yang diperoleh subjek dalam proses menyelesaikan masalah, juga dilakukan untuk mendapatkan hasil dari uraian secara lengkap terkait gestur siswa pada saat menyelesaikan masalah program linear.

Analisis data dalam penelitian ini yang pertama, dari hasil tes kemampuan awal siswa diklasifikasikan kemampuan awalnya terpenuhi atau tidak pada materi program linear. Adapun klasifikasinya dapat dilihat pada Tabel 2.

Tabel 2. Klasifikasi Kemampuan Awal Siswa

\begin{tabular}{|c|c|}
\hline Klasifikasi & Skor \\
\hline Terpenuhi & $80-100$ \\
\hline Belum Terpenuhi & $<80$ \\
\hline
\end{tabular}

Kedua, hasil tes penyelesaian masalah pada dua subjek yang dipilih dianalisis bersamaan dengan hasil observasi dan hasil wawancaranya. Ketiga, penarikan kesimpulan mengenai karakterisasi disposisi matematis dengan membandingkan tindakan subjek berupa gestur tubuh dengan apa yang ditulis dan dikatakan subjek dalam menyelesaikan masalah program linear. Kesesuaian terhadap tes, wawancara dan hasil observasi tersebut akan diperoleh data yang valid serta dapat digunakan dalam analisis data. Secara umum, road map karakterisasi disposisi matematis dapat dilihat dalam 
Gambar 1.

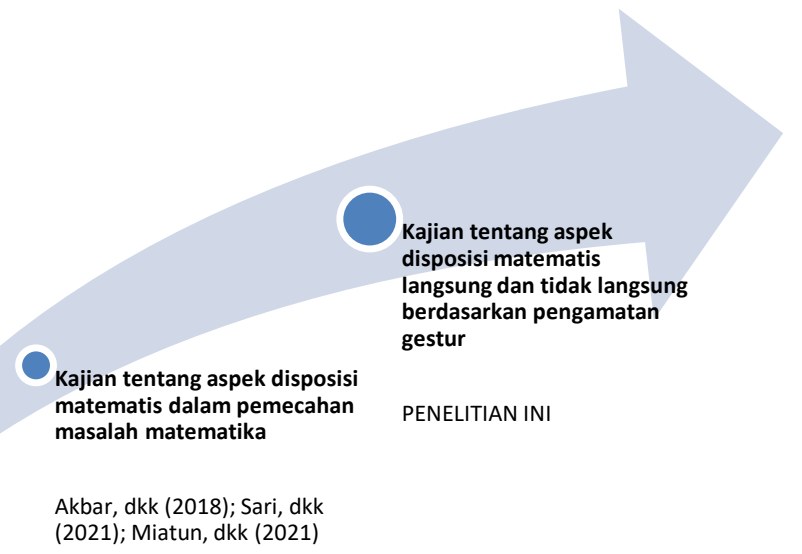

Gambar 1. Road Map Karakterisasi Disposisi Matematis

\section{HASIL DAN DISKUSI}

Berdasarkan hasil tes kemampuan awal pada materi program linear yang diambil dari 22 siswa melalui form yang telah disediakan. Terdapat 9 siswa dengan kemampuan awal pada kemampuan awal pada program linear terpenuhi, 13 diantara kemampuan awalnya tidak terpenuhi.

Tabel 3. Hasil Klasifikasi Kemampuan Awal Siswa

\begin{tabular}{|c|c|c|c|c|c|c|}
\hline $\begin{array}{c}\text { Kode } \\
\text { siswa }\end{array}$ & $\begin{array}{c}\text { Penguasaan } \\
\text { Prosedural }\end{array}$ & $\begin{array}{c}\text { Penguasaan } \\
\text { Konseptual }\end{array}$ & $\begin{array}{c}\text { Penguasaan } \\
\text { Teknik }\end{array}$ & $\begin{array}{c}\text { Penguasaan } \\
\text { Gabungan }\end{array}$ & Skor & Klasifikasi \\
\hline 01 & 4 & 5 & 4 & 3 & 80 & Memenuhi \\
\hline 02 & 4 & 5 & 5 & 2 & 80 & Memenuhi \\
\hline 03 & 3 & 4 & 5 & 4 & 80 & Memenuhi \\
\hline 04 & 3 & 4 & 5 & 4 & 80 & Memenuhi \\
\hline 05 & 4 & 5 & 3 & 4 & 80 & Memenuhi \\
\hline 06 & 4 & 5 & 6 & 3 & 90 & Memenuhi \\
\hline 07 & 3 & 4 & 4 & 4 & 75 & $\begin{array}{c}\text { Tidak } \\
\text { Memenuhi }\end{array}$ \\
\hline 08 & 3 & 4 & 5 & 4 & 80 & Memenuhi \\
\hline 09 & 4 & 4 & 5 & 4 & 85 & Memenuhi \\
\hline 10 & 4 & 4 & 4 & 2 & 70 & $\begin{array}{c}\text { Tidak } \\
\text { Memenuhi }\end{array}$ \\
\hline 11 & 2 & 2 & 0 & 0 & 20 & $\begin{array}{c}\text { Tidak } \\
\text { Memenuhi }\end{array}$ \\
\hline 12 & 4 & 4 & 4 & 2 & 70 & $\begin{array}{c}\text { Tidak } \\
\text { Memenuhi }\end{array}$ \\
\hline 13 & 4 & 5 & 6 & 1 & 80 & Memenuhi \\
\hline 14 & 4 & 2 & 2 & 0 & 40 & $\begin{array}{c}\text { Tidak } \\
\text { Memenuhi }\end{array}$ \\
\hline 15 & 4 & 4 & 3 & 1 & 60 & $\begin{array}{c}\text { Tidak } \\
\text { Memenuhi }\end{array}$ \\
\hline 16 & 4 & 3 & 2 & 3 & 60 & $\begin{array}{c}\text { Tidak } \\
\text { Memenuhi }\end{array}$ \\
\hline 17 & 3 & 4 & 1 & 4 & 60 & \begin{tabular}{c} 
Tidak \\
\hline
\end{tabular} \\
\hline & & & & & &
\end{tabular}


Disposisi Matematis Langsung dan Tidak Langsung: Karakteristisasi Disposisi Matematis Berdasarkan Gestur, Okta Pita Dian Sari, Surya Sari Faradiba

\begin{tabular}{|c|c|c|c|c|c|c|}
\hline 18 & 3 & 3 & 4 & 1 & 55 & $\begin{array}{c}\text { Memenuhi } \\
\text { Tidak } \\
\text { Memenuhi }\end{array}$ \\
\hline 19 & 4 & 4 & 5 & 2 & 75 & $\begin{array}{c}\text { Tidak } \\
\text { Memenuhi }\end{array}$ \\
\hline 20 & 4 & 4 & 3 & 3 & 70 & $\begin{array}{c}\text { Tidak } \\
\text { Memenuhi }\end{array}$ \\
\hline 21 & 4 & 2 & 1 & 1 & 40 & $\begin{array}{c}\text { Tidak } \\
\text { Memenuhi }\end{array}$ \\
\hline 22 & 3 & 3 & 4 & 2 & 60 & $\begin{array}{c}\text { Tidak } \\
\text { Memenuhi }\end{array}$ \\
\hline
\end{tabular}

Dari 9 siswa yang kemampuan awalnya terpenuhi diambil dua siswa sebagai subjek 1 (S1) dan subjek 2 (S2) untuk dieksplorasi mengenai karakterisasi disposisi matematisnya. Temuan yang didapatkan dalam penelitian ini yaitu disposisi langsung dan disposisi tidak langsung pada siswa saat menyelesaikan masalah program linear. Disposisi langsung yaitu istilah yang digunakan untuk menggambarkan proses penyelesaian masalah yang terjadi seketika saat siswa menemui hambatan, dalam hal ini siswa tanpa ada persiapan dapat menghadapinya seketika. Sedangkan, disposisi tidak langsung yaitu istilah yang digunakan untuk menggambarkan proses penyelesaian masalah yang terjadi beberapa saat setelah siswa menemui hambatan, dalam hal ini perlu adanya stimulus untuk menghadapi hambatan tersebut. Adapun hasil karakterisasi disposisi matematis pada S1 ditunjukkan pada Tabel 4.

Tabel 4. Hasil Karakterisasi Disposisi Matematis Melalui Gestur S1

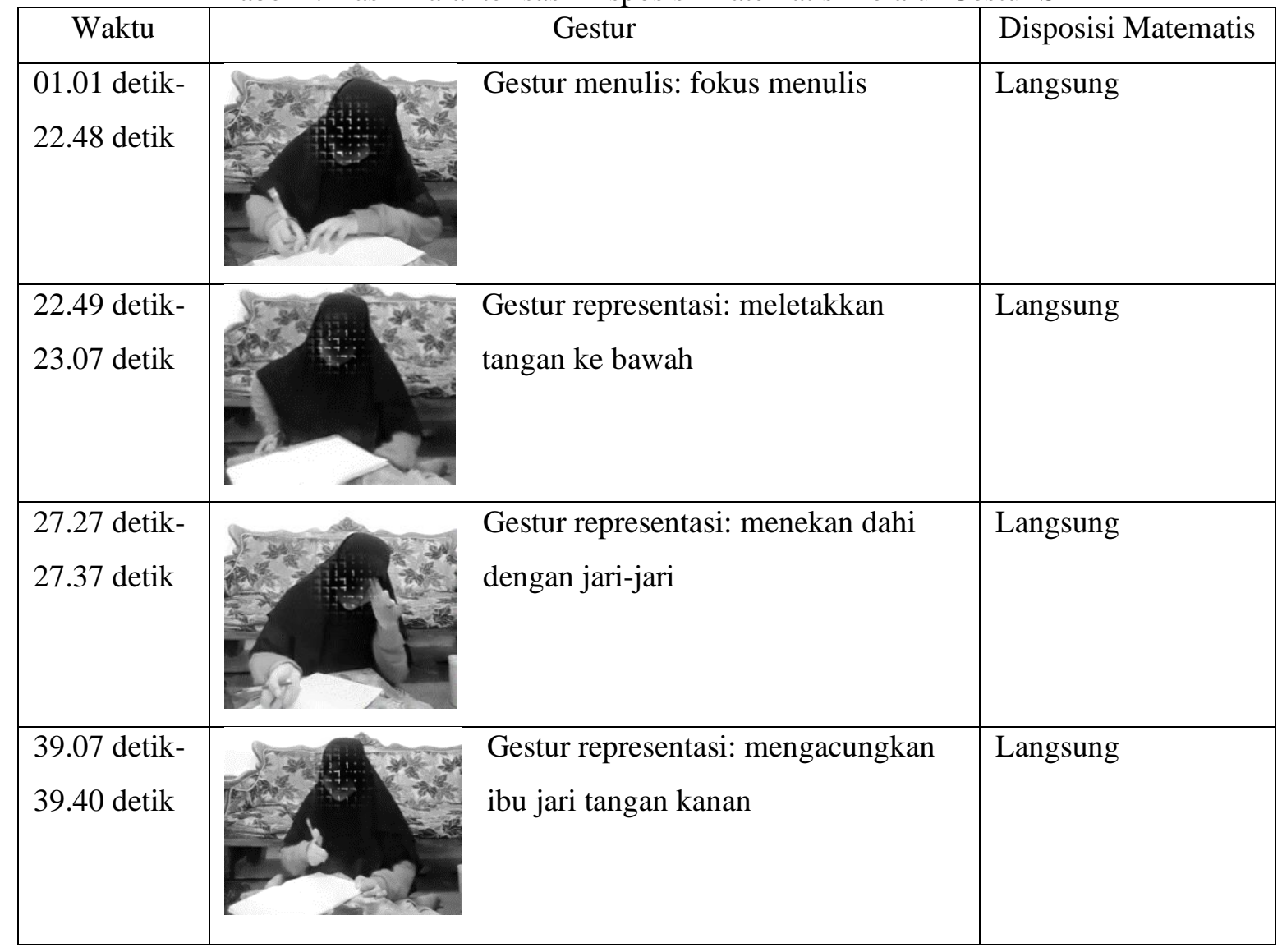


Berdasarkan hasil karakterisasi disposisi matematis melalui gestur pada Tabel 3, S1 menyelesaikan masalah tepat waktu yaitu selama 40 menit. S1 selama menyelesaikan masalah menemukan beberapa hambatan namun dapat diatasinya sendiri tanpa bantuan peneliti. Sehingga, S1 hanya memiliki disposisi langsung.

S1 menunjukkan gestur menulis yang ditunjukkan pada menit awal, yaitu fokus menulis selama dua puluh satu menit lebih empat puluh tujuh detik. Ungkapan emosional dan pemikiran dituangkan dalam tulisan. Sejalan dengan Achadiyah (2017) gestur menulis menunjukkan bahwa apa yang sudah diketahui dalam pikirannya sebagai bentuk akhir yang dituangkan dalam tulisan.

Namun, S1 ternyata memiliki hambatan memahami konsep tetapi dapat menyelesaikan masalahnya secara langsung. Hal ini ditunjukkan dengan wawancara peneliti (P) setelah subjek 1 (S1) menyelesaikan masalah.

\section{P : "Apakah kamu mengalami hambatan di awal dalam menyelesaikan masalah?"}

S1: "Iya Bu. Saya sempat lupa beberapa konsep. Tapi saya langsung ingat."

Kemudian, S1 mengalami hambatan dengan menunjukkan gestur representasi berupa meletakkan tangan ke bawah. Gestur ini menggambarkan kondisi emosionalnya karena mendapatkan suatu hambatan yang mana ditunjukkan pada wawancara seketika terhadap S1.

$P$ : “Apakah ada masalah?"

S1: "Saya hampir menggambar grafik, padahal titik potongnya belum ketemu."

Hal ini juga dibuktikan dengan hasil kerja S1 yang mencoret angka 400 dan 200 karena akan menggambarkan grafik. Adapun bukti hasil kerja S1 dapat dilihat pada Gambar 2.

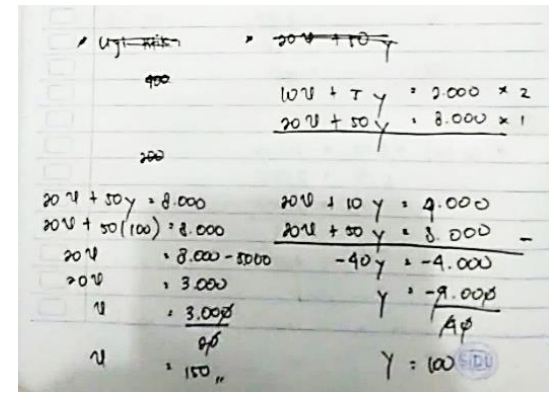

Gambar 2. Hasil Kerja S1 Saat Menyadari Kesalahan

Dengan memberikan jeda waktu dengan representasi yang ditunjukkan, S1 dapat menemukan kesalahan yang dilakukan yaitu tidak menuliskan langkah menemukan titik potong. Kemudian subjek memperbaikinya. Gestur representasi dapat memberikan hubungan antara pemikiran sebelumnya ke pemikiran berikutnya (Sulistyorini, dkk, 2019)

Gestur representasi lain yang ditunjukkan oleh S1 yaitu menekan dahi dengan jari-jari tangan kirinya. S1 menekan dahi dikarenakan berada dalam kondisi bingung. Sejalan dengan Kurniati (2016) menyatakan bahwa seseorang dalam kondisi bingung, secara tidak sadar akan menggigit bibir, menyentuh area wajah ataupun memainkan pensil. Untuk memahami lebih lanjut disposisi matematis S1, maka peneliti melakukan wawancara. Berikut cuplikan wawancara antara peneliti dan S1. 
$P$ : "Apakah ada kesulitan?"

S1: "Saya bingung dalam menentukan daerah arsiran."

(Setelah ditunggu selama 10 detik, peneliti memberikan bantuan)

$P$ : "Apakah kamu memerlukan bantuan?"

S1 : "Tidak Bu. Saya coba selesaikan sebisa saya." (muncul sikap ingin berusaha menyelesaikan)

Berdasarkan hasil wawancara dapat diketahui bahwa gestur representasi pada S1 diakibatkan karena S1 bingung menghadapi hambatan yang muncul. Hasil kerja perlu ditunjukkan untuk mengetahui apakah S1 bisa menyelesaikan sendiri. Adapun hasil kerja S1 dapat dilihat pada Gambar 3.

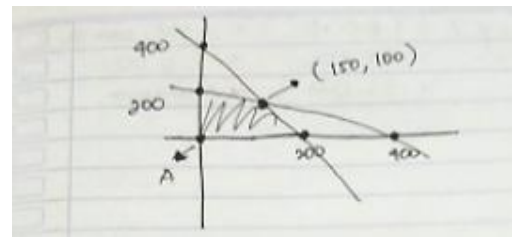

Gambar 3. Hasil Kerja S1 dalam Menggambar Grafik

Gambar 2 menunjukkan bahwa S1 dapat menyelesaikan hambatan yang terjadi tanpa bantuan dari peneliti. Walaupun, $\mathrm{S} 1$ tidak menuliskan syarat dalam menggambarkan daerah arsir yaitu $\mathrm{x} \geq 0$ dan $\mathrm{y}$ $\geq 0$ selain itu syarat lainnya yaitu $20 x+50 y \leq 800$ dan $10 x+5 y \leq 400$.

Selanjutnya, S1 selama sepuluh detik juga menunjukkan gestur representasi yaitu mengacungkan ibu jari tangan kanannya. Peneliti langsung memberikan wawancara seketika kepada S1.

P: "Mengapa kamu terlihat senang?"

S: "Saya sudah menemukan jawabannya dan yakin benar." (muncul sikap percaya diri)

Berdasarkan jawaban dari S1, gestur representasi mewakili rasa senang karena dapat menemukan hasil maksimum dan yakin bahwa jawabannya benar. Didukung dengan Kurniati (2016) bahwa mengacungkan jari bermakna kemenangan. Adapun Hasil Akhir S1 ditunjukkan pada Gambar 4.

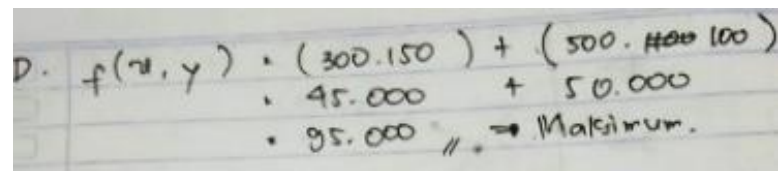

Gambar 4. Hasil Akhir S1

Selanjutnya, akan ditunjukkan hasil karakterisasi disposisi matematis melalui gestur S2 yang dapat dilihat pada Tabel 5. Berdasarkan hasil karakterisasi disposisi matematis melalui gestur pada Tabel 4, S2 menyelesaikan masalah tepat waktu yaitu selama 40 menit. S2 selama menyelesaikan masalah menemukan beberapa hambatan. Dalam menghadapi hambatannya, S2 memerlukan adanya stimulus yang diberikan peneliti pada saat wawancara seketika. Selama sembilan belas menit lebih empat puluh detik S2 fokus menulis, sehingga gestur yang diberikan S2 diawal adalah gestur menulis. Sejalan dengan Achadiyah (2017) gestur menulis menunjukkan bahwa apa yang sudah diketahui dalam pikirannya sebagai bentuk akhir yang dituangkan dalam tulisan. Namun, S2 ternyata memiliki 
hambatan memahami konsep tetapi dapat menyelesaikan masalahnya secara langsung. Hal ini ditunjukkan dengan wawancara peneliti (P) setelah subjek 2 (S2) menyelesaikan masalah.

P : "Apakah kamu mengalami hambatan di awal dalam menyelesaikan masalah?"

S2: "Iya Bu. Saya awal-awal menemukan hambatan yaitu lupa konsep uji titik. Tapi langsung ingat."

Tabel 5. Hasil Karakterisasi Disposisi Matematis Melalui Gestur S2

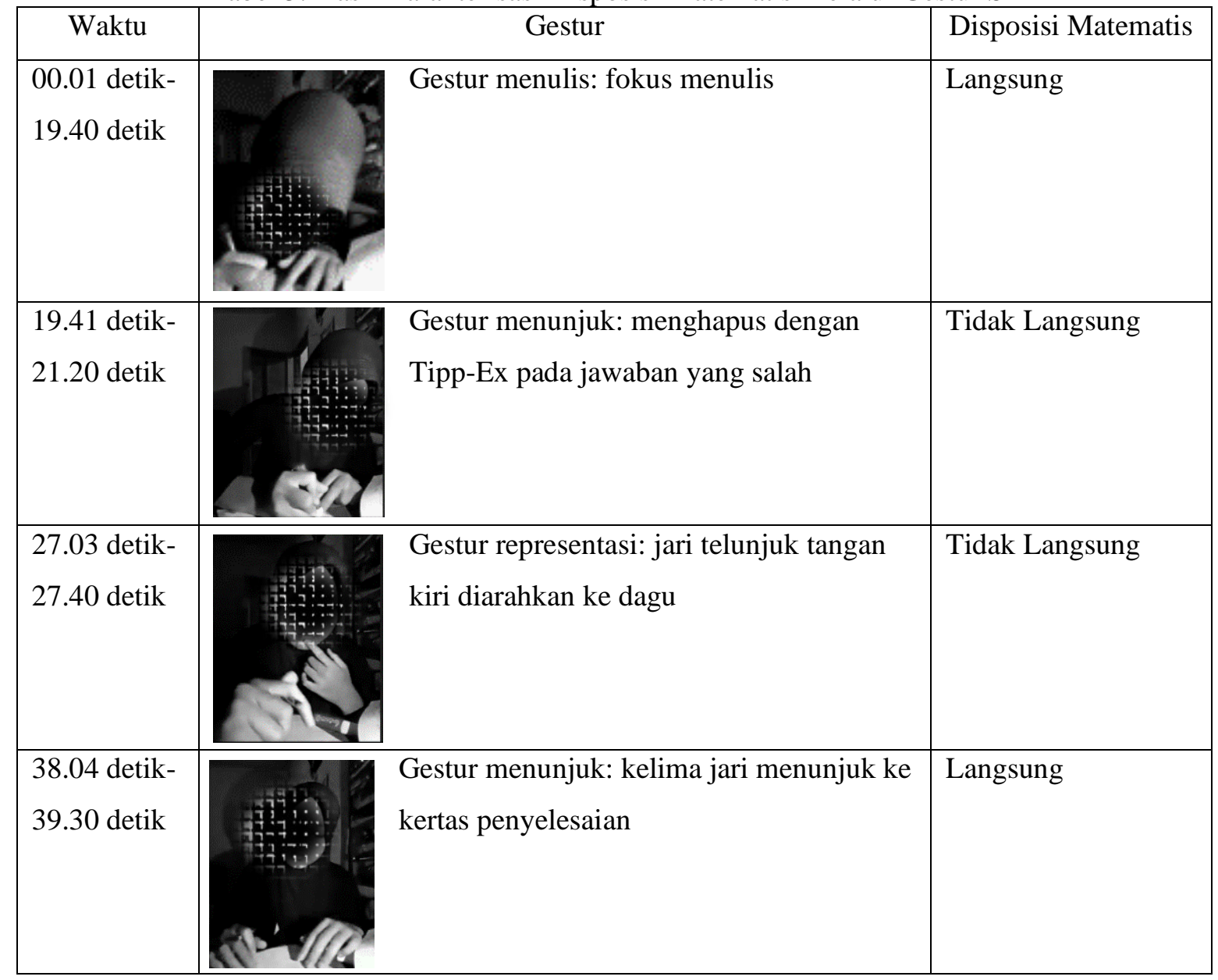

Kemudian, S2 memberikan gestur menunjuk berupa gerakan menghapus dengan Tipp-Ex pada jawaban yang ingin dihapus yaitu salah dalam menuliskan cara eliminasi dan substitusi. Gestur menunjuk menandakan bahwa S2 sedang memberikan informasi bagian yang menurut dia salah. Sependapat dengan Elvierayani (2016) bahwa gestur menunjuk dapat mempermudah seseorang untuk memberikan informasi sesuai dengan yang dipikirkan seseorang.

S2 mendapatkan bantuan dari peneliti untuk mengatasi hambatan yang dihadapinya. Hambatan diketahui peneliti setelah peneliti memberikan wawancara seketika pada S2.

$P$ : "Apakah yang sedang kamu hapus?"

S2: "Saya tidak menemukan $x$ dan y, padahal sudah saya eliminasi dan substitusi. Jadi saya hapus." $P$ : "Lalu apa langkah yang kamu lakukan?"

S2: “Tidak tau Bu. Sepertinya saya selesai disini saja.” (muncul sikap tidak percaya diri) 
$P$ : “Apa syarat kalau ingin mengeliminasi?" (peneliti memberi petunjuk)

S2: "Lupa Bu."

$P$ : “Agar mendapatkan salah satu nilai $x$ atau y, harus disamakan salah satu apanya?” (peneliti memberi petunjuk)

S2: "Oh iya. Variabelnya."

Berdasarkan disposisi matematis tidak langsung yang ditunjukkan S2. Muncul sikap tidak percaya diri karena tidak dapat menghadapi hambatan. Adapun hasil kerja S2 dapat dilihat pada Gambar 5.

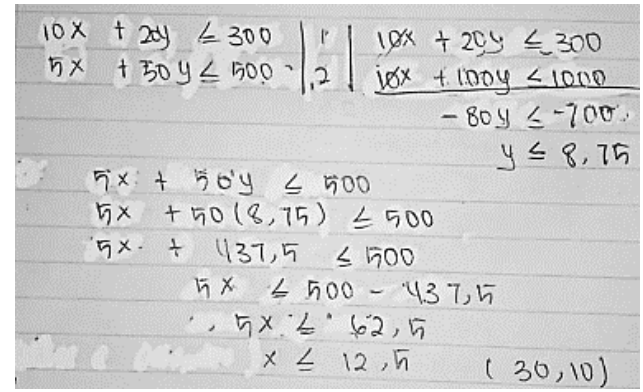

Gambar 5. Hasil Kerja S2 Setelah Mendapatkan Bantuan

Selain memberikan gestur menulis dan menunjuk, S2 menunjukkan gestur representasi yaitu jari telunjuk tangan kiri diarahkan ke dagu. S2 menunjukkan adanya hambatan yaitu bingung menentukan titik C. Sejalan dengan Kurniati (2016) menyatakan bahwa seseorang dalam kondisi bingung, secara tidak sadar akan menggigit bibir, menyentuh area wajah ataupun memainkan pensil. Hal ini ditunjukkan pada wawancara seketika yang dilakukan peneliti.

$P$ : “Apakah kamu menemukan hambatan?"

S2: "Saya bingung mensubstitusikan pada bagian titik C Bu."

$P$ : "Apa yang kamu bingungkan?"

S2: "Yang saya substitusikan itu harus titiknya atau hasil eliminasi dan substitusi saya ya Bu?"

$P$ : “Coba diingat kembali." (peneliti memberi bantuan)

(Setelah ditunggu 10 detik, S2 tidak memberi respon. Peneliti memberi bantuan lagi)

S2: "Kalau titik A dan B kamu disubstitusikan hasil eliminasi dan substitusi tadi, berarti untuk titik $C$ bagaimana?" (peneliti memberi bantuan)

$P$ : "Berarti bukan titiknya ya Bu. Paham Bu."

Berdasarkan wawancara seketika yang diperoleh, maka perlu adanya bukti hasil kerja S2 untuk mengetahui apakah S2 menuliskan sesuai dengan petunjuk yang peneliti berikan. Adapun hasil kerja S2 dapat dilihat pada Gambar 6.

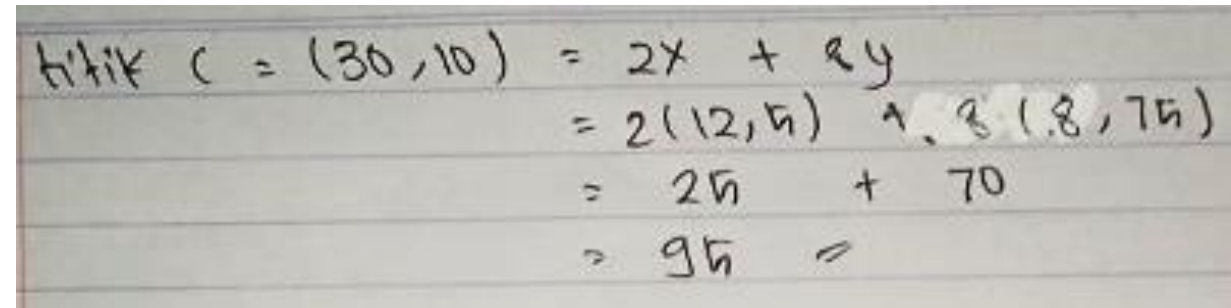

Gambar 6. Hasil Kerja S2 dalam Menentukan Titik C 
Gestur terakhir yaitu S2 memberikan gestur menunjuk berupa kelima jari kanan dan kiri menunjuk ke kertas penyelesaian. Gestur menunjuk dapat mempermudah untuk memberikan informasi sesuai dengan yang dipikirkan seseorang Elvierayani (2016). Gestur tersebut disebabkan karena S2 sedang mencoba mengingat konsep menentukan daerah arsir berdasarkan wawancara seketika yang dilakukan peneliti.

$P$ : “Apakah kamu sudah selesai pada jawabanmu?"

S2: "Masih mengingat daerah arsir Bu."

$P$ : “Apakah perlu bantuan?"

S2: "Tidak Bu. Saya sebenarnya sudah tau, tapi mencoba meyakinkan kembali."

Berdasarkan hasil wawancara seketika. Ditunjukkan hasil kerja S2 dalam menentukan daerah arsiran yang dapat dilihat pada Gambar 7.

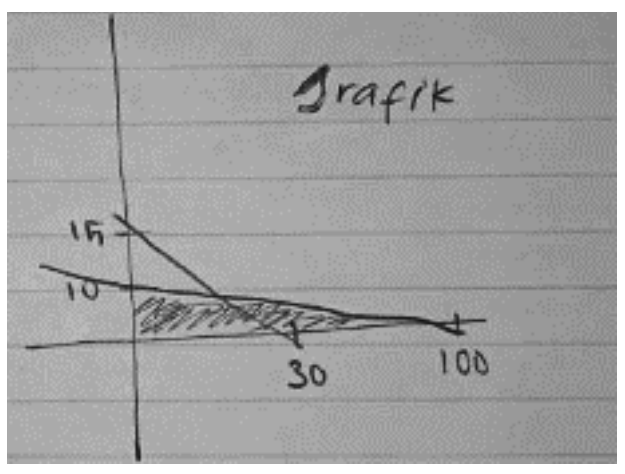

Gambar 7. Hasil Kerja S2 dalam Menentukan Daerah Arsiran

Berdasarkan pembahasan hasil karakterisasi disposisi matematis melalui gestur pada S1 dan S2 menunjukkan bahwa S1 terus menunjukkan adanya disposisi langsung. Sedangkan S2 selama penyelesaian menunjukkan adanya disposisi langsung dan tidak langsung. Secara umum, karakterisasi disposisi matematis berdasarkan gestur dari dua subjek dalam penelitian ini dapat dilihat pada Tabel 5.

Tabel 5. Karakterisasi Disposisi Matematis Berdasarkan Gestur

\begin{tabular}{|c|c|c|c|c|}
\hline \multirow{2}{*}{ Subjek } & \multicolumn{3}{|c|}{ Gestur } & Disposisi \\
\cline { 2 - 4 } & Menulis & Menunjuk & Representasi & Matematis \\
\hline S1 & $\begin{array}{c}\text { Ditunjukkan sebanyak } \\
1 \text { kali }\end{array}$ & $\begin{array}{c}\text { Tidak ada gestur } \\
\text { menunjuk }\end{array}$ & $\begin{array}{c}\text { Ditunjukkan } \\
\text { sebanyak 3 kali }\end{array}$ & Langsung \\
\hline S2 & $\begin{array}{c}\text { Ditunjukkan sebanyak } \\
1 \text { kali }\end{array}$ & $\begin{array}{c}\text { Ditunjukkan } \\
\text { sebanyak 1 kali }\end{array}$ & $\begin{array}{c}\text { Ditunjukkan } \\
\text { sebanyak 2 kali }\end{array}$ & $\begin{array}{c}\text { Langsung dan } \\
\text { Tidak Langsung }\end{array}$ \\
\hline
\end{tabular}

\section{KESIMPULAN}

Berdasarkan analisis data dan temuan diperoleh kesimpulan bahwa gestur yang mendominasi adalah gestur representasi. S1 menunjukkan tiga kali gestur representasi, sedangkan S2 menunjukkan dua kali gestur representasi. Melalui gestur, diperoleh petunjuk untuk mengungkapkan disposisi matematis langsung dan tidak langsung. S1 terus menunjukkan adanya disposisi langsung, sedangkan S2 menunjukkan disposisi langsung dan tidak langsung sekaligus selama menyelesaikan masalah. Disposisi langsung yaitu istilah yang digunakan untuk menggambarkan proses penyelesaian 
masalah yang terjadi seketika saat siswa menemui hambatan, dalam hal ini siswa tanpa ada persiapan dapat menghadapinya seketika. Sedangkan, disposisi tidak langsung yaitu istilah yang digunakan untuk menggambarkan proses penyelesaian masalah yang terjadi beberapa saat setelah siswa menemui hambatan.

\section{UCAPAN TERIMA KASIH}

Ucapan terimakasih peneliti kepada MAN Kota Batu yang telah mengijinkan penelitian ini sehingga dapat terlaksana dengan baik. Terimakasih juga peneliti ucapkan kepada para dosen dan mahasiswa magister pendidikan matematika program pascasarjana Universitas Islam Malang yang telah membantu dalam proses penelitian.

\section{REFERENSI}

Achadiyah, N. L. 2017. Gestur Siswa Sekolah Menengah Pertama dalam Memecahkan Masalah Matematis secara Berkelompok. Suska Journal of Mathematics Education, 3(1), 49-56.

Akbar, P., Hamid, A., Bernard, M., \& Sugandi, A. I. 2017. Analisis Kemampuan Pemecahan Masalah Dan Disposisi Matematik Siswa Kelas XI SMA Putra Juang dalam Materi Peluang. Jurnal Cendekia : Jurnal Pendidikan Matematika, 2(1), 144-153.

Alibali, M. W., \& Nathan, M. J. 2012. Embodiment in Mathematics Teaching and Leaning: Evidence from Learner's and Teahcer's Gestures. Journal of The Learning Sciences, 21, 247-286.

Andriyani, A., \& Ratu, N. 2018. Soal Cerita Pada Materi Program Linear Ditinjau Dari Gaya Kognitif Siswa. Jurnal Pendidikan Berkarakter, 1(1), 16-22.

Damayanti, N. W. 2018. Profil Gesture Mahasiswa dalam Representasi Diagonal Sisi dan Diagonal Ruang pada Kubus. EDU-MAT: Jurnal Pendidikan Matematika, 6(2), 171-177.

Elvierayani, R. R. 2016. Gesture Matematis Siswa dalam Menyelesaikan Masalah Fungsi. Jurnal Reforma, 4(1), 10-18.

Harun, L., Darhim, D., Dahlan, J. A., Harisman, Y., Sovia, A., \& Bakar, M. T. 2019. Students' gesture of naive, routine, and shopisticated behavior oriented on mathematical problem solving. Journal of Physics: Conference Series, 1157(4).

Hendriana, H., \& Kadarisma, G. 2019. Self-Efficacy dan Kemampuan Komunikasi Matematis Siswa SMP. JNPM (Jurnal Nasional Pendidikan Matematika), 3(1), 153-164.

Kurniati, D. P. Y. 2016. Modul Komunikasi Verbal dan Non Verbal. Program Studi Kesehatan Masyarakat Fakultas Kedokteran, Universitas Udayana.

Kurnia D, S. W., Sutiarso, S., \& Yunarti, T. 2014. Analisis Kesalahan Siswa dalam Menyelesaikan Soal Cerita pada Pembelajaran Matematika. Jurnal Pendidikan Matematika Universitas Lampung, 2(1), 356-362.

Miatun, A., Khusna, H., \& Slamet. 2021. Van Hiele Levels: Errors in Solving Geometry Problems from Mathematical Disposition. Journal of Physics: Conference Series, 1933(1), 1-8. 
National Council of Teachers of Mathematics. 1989. Curriculum and Evaluation Standards For School Mathematics. Reston, VA: Author.

Sari, O. P. D., Zainal, A., \& Faradiba, S. S. 2021. Analisis Kemampuan Pemecahan Masalah Berdasarkan Disposisi Matematis Pada Materi Trigonometri Peserta Didik Kelas X Bahasa MAN Kota Batu. Jurnal Penelitian, Pendidikan, Dan Pembelajaran, 16(12), 1-14.

Sulistiyaningsih, A. 2017. Analisis Kesalahan Sisa menurut Kastolan dalam Pemecahan Masalah Matematika. Prosiding Seminar Matematika Pendidikan Matematika yang diselenggarakan oleh Universitas Negeri Yogyakarta, tanggal 11 mei 2017. Yogyakarta: Universitas Negeri Yogyakarta.

Sulistyorini, Y., Studi, P., \& Matematika, P. 2019. Gestur dalam Pembelajaran Matematika Materi Irisan Kerucut dan Koordinat Polar. Jurnal Pendidikan Matematika, 3(1), 1-9.

Wahab, R. 2015. Psikologi belajar. Depok : PT Raja Grafindo Persada.

Wardani. 2012. Pembelajaran Inkuiri Model Silver Untuk Mengembangkan Kemampuan Pemecahan Masalah dan Disposisi Matematik Siswa Sekolah Menengah Atas. Jurnal Pendidikan Matematika, 1(1), 9-16.

Williams, C., Pier, E. L., Walkington, C., Boncoddo, R., Clinton, V., Nathan, M. W. A. \& Nathan, M. J. 2017. What We Say and How We Do: Action, Gesture, and Language in Proving. ucation, Journal for Research in Mathematics Education, 48(3), 248-260.

Yuli, T., \& Siswono, E. 2019. Students gestures in understanding algebraic concepts. Beta: Jurnal Tadris Matematika, 12(24), 134. 